\title{
Extracellular calcium triggers unique transcriptional programs and modulates staurosporine-induced cell death in Neurospora crassa
}

\author{
A. Pedro Gonçalves ${ }^{1,2, *}$, João Monteiro' ${ }^{2}$, Chiara Lucchi ${ }^{2}$, David J. Kowbel ${ }^{3}$, J. Miguel Cordeiro ${ }^{1,4}$, Paulo \\ Correia-de-Sá1,4 $^{1,}$ Daniel J. Rigden ${ }^{5}$, N. Louise Glass ${ }^{3}$, Arnaldo Videira ${ }^{1,2, *}$ \\ ${ }^{1}$ ICBAS-Instituto de Ciências Biomédicas de Abel Salazar, Universidade do Porto, Rua de Jorge Viterbo Ferreira 228, 4050-313 Porto, \\ Portugal. \\ ${ }^{2}$ IBMC-Instituto de Biologia Molecular e Celular - Universidade do Porto, Rua do Campo Alegre 823, 4150-180 Porto, Portugal. \\ 3 Plant and Microbial Biology Department, The University of California, Berkeley, CA 94720, USA. \\ 4 UMIB-Unidade Multidisciplinar de Investigação Biomédica, Universidade do Porto, Rua de Jorge Viterbo Ferreira 228, 4050-313 \\ Porto, Portugal. \\ 5 Institute of Integrative Biology, University of Liverpool, Liverpool, L69 7ZB, United Kingdom. \\ * Corresponding Authors: A. Pedro Gonçalves, ICBAS-Instituto de Ciências Biomédicas de Abel Salazar, Universidade do Porto, Rua de \\ Jorge Viterbo Ferreira 228; 4050-313 Porto, Portugal; E-mail: apgoncalves@ibmc.up.pt AND Arnaldo Videira, ICBAS-Instituto de \\ Ciências Biomédicas de Abel Salazar, Universidade do Porto, Rua de Jorge Viterbo Ferreira 228; 4050-313 Porto, Portugal; E-mail: \\ avideira@ibmc.up.pt
}

\begin{abstract}
Alterations in the intracellular levels of calcium are a common response to cell death stimuli in animals and fungi and, particularly, in the Neurospora crassa response to staurosporine. We highlight the importance of the extracellular availability of $\mathrm{Ca}^{2+}$ for this response. Limitation of the ion in the culture medium further sensitizes cells to the drug and results in increased accumulation of reactive oxygen species (ROS). Conversely, an approximately 30 -fold excess of external $\mathrm{Ca}^{2+}$ leads to increased drug tolerance and lower ROS generation. In line with this, distinct staurosporine-induced cytosolic $\mathrm{Ca}^{2+}$ signaling profiles were observed in the absence or presence of excessive external $\mathrm{Ca}^{2+}$. High-throughput RNA sequencing revealed that different concentrations of extracellular $\mathrm{Ca}^{2+}$ define distinct transcriptional programs. Our transcriptional profiling also pointed to two putative novel $\mathrm{Ca}^{2+}$ binding proteins, encoded by the NCU08524 and NCU06607 genes, and provides a reference dataset for future investigations on the role of $\mathrm{Ca}^{2+}$ in fungal biology.
\end{abstract}

doi: $10.15698 /$ mic2014.09.165 Received originally: 23.06 .2014 ; in revised form: 22.07.2014, Accepted 23.07.2014

Published 09.08.2014.

Keywords: calcium, cell death, ROS, Ca2+-binding motif, Neurospora crassa.

\section{INTRODUCTION}

Calcium $\left(\mathrm{Ca}^{2+}\right)$ is crucial for diverse processes in fungi, including tip growth, virulence, circadian rhythms, nutrient sensing, cell wall regeneration, chemotropic interaction and cell death [1]. $\mathrm{Ca}^{2+}$ and cell death are intimately connected, especially because of the vital role of $\mathrm{Ca}^{2+}$ as an intracellular messenger affecting numerous signaling pathways that determine cell fate. Therefore, it is not surprising that cells commonly respond to cell death stimuli with rises in the intracellular levels of this divalent ion. On one hand, these transient or stable modifications in the levels of $\mathrm{Ca}^{2+}$ can operate as survival signals, leading to the activity of anti-death proteins or stimulating transcriptional defence responses. On the other hand, the loss of $\mathrm{Ca}^{2+}$ homeostasis can behave as a pro-death signal, since in some systems overload or a simple perturbation of the distribution of the ion within storage organelles is sufficient to trigger cell death [2]. In yeast species like Saccharomyces cerevisiae, Candida albicans and Cryptococcus neoformans, cytosolic $\mathrm{Ca}^{2+}$ increases are a common feature of the cellular response to a number of antifungal stresses, including pheromone [3], the plant essential oils carvacrol [4] and eugenol [5], amiodarone [3, 6], and ER stressinducing agents like tunicamycin and azole drugs $[7,8]$. In $N$. crassa, a rise in the cytosolic levels of $\mathrm{Ca}^{2+}$ was associated with cell death induced by chitosan [9], Penicillium chrysogenum protein PAF [10], PAF26 [11] and staurosporine [12].

We have been using $N$. crassa to investigate the molecular mechanisms underlying the cell death process in- 
duced by the bacterial alkaloid staurosporine. Treatment with staurosporine leads to a complex response that includes the efflux of reduced glutathione (GSH), with a concomitant change in the intracellular redox state to a more oxidative environment and the consequent accumulation of reactive oxygen species (ROS) $[13,14]$. The drug also activates a drug resistance pathway that comprises the zinc binuclear cluster transcription factor CZT-1 [15] and ABC-3, an ATP-binding cassette $(A B C)$ transporter [16]. A combined genetic and pharmacological strategy coupled to measurements of cytosolic alterations in $\mathrm{Ca}^{2+}$ levels with the photoreporter aequorin revealed a three-step signature response to the drug that involves mobilization of the ion from intracellular stores as well as uptake from the external medium. $N$. crassa is a good model for the study of $\mathrm{Ca}^{2+}$ dynamics as sequencing of its genome revealed a rich and versatile assortment of molecules involved in $\mathrm{Ca}^{2+}$ homeostasis, including channels, pumps and signaling transducers [17-19]. A substantial fraction of the genome, however, remains to be characterized and additional unknown members of $\mathrm{Ca}^{2+}$ machinery may exist. The beststudied $\mathrm{Ca}^{2+}$-binding moiety is the classical EF-hand, in which a $\mathrm{Ca}^{2+}$-interacting loop is flanked by two helices [20]. However, there are variations on this motif, especially at the structural level, and it is now accepted that more than a dozen different types of $\mathrm{Ca}^{2+}$-binding domains exist [21]. In particular, several proteins classes were shown to carry convergently evolved $\mathrm{Ca}^{2+}$-binding $\mathrm{Dx}[\mathrm{DN}] \times \mathrm{XDG}$ motifs. The distinct evolutionary origins of the motif are evident from the variability of structural contexts flanking the $\mathrm{Ca}^{2+}$ binding region $[22,23]$. Though initially identified in bacteria [24], it was later perceived that this motif is widespread across all kingdoms $[22,23]$, including in a fungal caleosin $[23,25]$ and lectin from Psathyrella velutina $[22,26]$.

We have recently shown that staurosporine-induced cell death in $N$. crassa involves a precise sequence of $\mathrm{Ca}^{2+}$ signaling events which are completely abolished by the inhibition of extracellular $\mathrm{Ca}^{2+}$ uptake [12]. Thus, we investigated the effects of the drug in N. crassa cells growing in limited or excessive amounts of the ion. The results presented here revealed that extracellular $\mathrm{Ca}^{2+}$ modulates cell death and the transcriptional alterations induced by staurosporine, and led to the identification of two novel putative $\mathrm{Ca}^{2+}$-binding proteins, encoded by the NCU08524 and NCU06607 genes.

\section{RESULTS}

The availability of extracellular $\mathrm{Ca}^{2+}$ impacts staurosporine-induced cell death and intracellular $\mathrm{Ca}^{2+}$ signaling

Intracellular $\mathrm{Ca}^{2+}$ dynamics play an important role during staurosporine-induced cell death in $N$. crassa, eliciting a complex response that includes $\mathrm{Ca}^{2+}$ release from internal stores as well as uptake from the extracellular space [12]. Thus, we tested the response to staurosporine of cells growing with different $\mathrm{Ca}^{2+}$ concentrations. We prepared a culture medium, designated 'no $\mathrm{Ca}^{2+}$ ', by removing $\mathrm{CaCl}_{2}$ from Vogel's minimal medium (MM) [27]. Small amounts of $\mathrm{Ca}^{2+}$ as impurities from the other reagents in the solu- tion allowed $N$. crassa to grow well under such conditions (Fig. 1A, middle panel). In contrasting experiments, we supplemented medium with $20 \mathrm{mM} \mathrm{CaCl}_{2}$ ('20 mM CaCl${ }_{2}^{\prime}$ medium), which represents an approximately 30 fold (but not toxic) increase as compared with the $0.68 \mathrm{mM} \mathrm{CaCl}_{2}$ present in standard Vogel's medium (Fig. 1A, lower panel). We inoculated wild type cells on the centre of Petri dishes containing standard, no $\mathrm{Ca}^{2+}$ or $20 \mathrm{mM} \mathrm{CaCl}_{2}$ solid Vogel's MM supplemented with staurosporine and measured radial growth during a 104 hour time course. The drug inhibited growth in all media (Fig. $1 \mathrm{~A}-\mathrm{C}$ ). However, the staurosporine inhibitory effect was amplified in the absence of $\mathrm{Ca}^{2+}$ (e.g., $39 \%$ of inhibition after 32 hours of treatment with $1 \mu \mathrm{M}$ staurosporine in no $\mathrm{Ca}^{2+}$ versus $~ 14 \%$ in standard $\mathrm{MM})$. On the other hand, growth inhibition was partially overcome in $20 \mathrm{mM} \mathrm{CaCl}_{2}$ medium (e.g., $37 \%$ of inhibition after 32 hours of treatment with $2.5 \mu \mathrm{M}$ staurosporine in $20 \mathrm{mM} \mathrm{CaCl}_{2}$ versus $\sim 65 \%$ in standard MM). In GFS medium, which contains sorbose that promotes colonial growth [28], the outcome of modifying the extracellular concentration of $\mathrm{Ca}^{2+}$ was similar: the effects of staurosporine were exacerbated in no $\mathrm{Ca}^{2+}$ medium whereas growth inhibition was partially suppressed in the presence of $20 \mathrm{mM} \mathrm{CaCl}_{2}$, (Fig. 1D). Enhancement and suppression of inhibition of growth by absence of $\mathrm{Ca}^{2+}$ and $20 \mathrm{mM} \mathrm{CaCl}_{2}$, respectively, was not reproduced when cells are treated with phytosphingosine (data not shown), another cell death inducer in $N$. crassa, supporting previous observations that staurosporine and phytosphingosine act by distinct mechanisms $[14,29,30]$.

In order to check cell death, we analysed cell staining with YOPRO-1 (early apoptosis marker) or PI (late apoptosis/necrosis marker) by flow cytometry. A 2-hour treatment with staurosporine in standard MM resulted in $\sim 22 \%$ and $\sim 17 \%$ of YOPRO-1 and PI positive cells, respectively (Fig. $1 \mathrm{E}-\mathrm{F})$. In no $\mathrm{Ca}^{2+}$ medium, these levels were augmented to $\sim 40 \%$ ( $p$-value $\sim 0$ ) and $\sim 34 \%$ ( $p$-value $=0.029)$, respectively (Fig. 1E-F). In contrast, the percentage of YOPRO-1 and PIpositive cells was reduced to $\sim 15 \%(p$-value $=0.042)$ and $\sim 6 \%$ ( $p$-value $=0.050)$, respectively, in $20 \mathrm{mM} \mathrm{CaCl}_{2}$ medium.

The production of ROS is an essential event during the response of $N$. crassa to staurosporine, as the addition of antioxidants blocks cell death [13]. We asked if the availability of $\mathrm{Ca}^{2+}$ in the culture medium influenced cellular ROS production induced by staurosporine. While in standard MM cells stressed for 30 minutes with staurosporine displayed a $\sim 4.2$ fold-increase in ROS accumulation, the equivalent accumulation was $\sim 10.4(p$-value $=0.001)$ and $\sim 1.3$ ( $p$-value $=0.014)$ in no $\mathrm{Ca}^{2+}$ and $20 \mathrm{mM} \mathrm{CaCl}_{2}$ media, respectively (Fig. 1G). Given the importance of ROS formation for cell death provoked by staurosporine, this $\mathrm{Ca}^{2+}$ ROS dependence is likely associated with the distinct cell death phenotypes in the different culture media.

To further stress the modulatory effect of altering the levels of $\mathrm{Ca}^{2+}$ in staurosporine-induced cell death, we combined the drug with the $\mathrm{Ca}^{2+}$ chelator BAPTA and the $\mathrm{Ca}^{2+}$ ionophore A23187 (calcimycin) in GFS plates with standard MM. As expected, extracellular $\mathrm{Ca}^{2+}$ blockage with BAPTA 
A

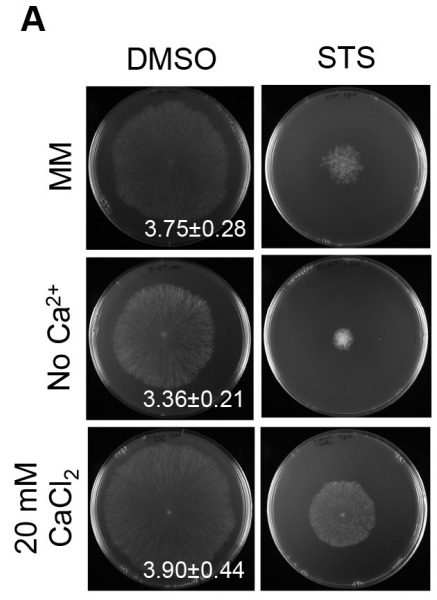

B

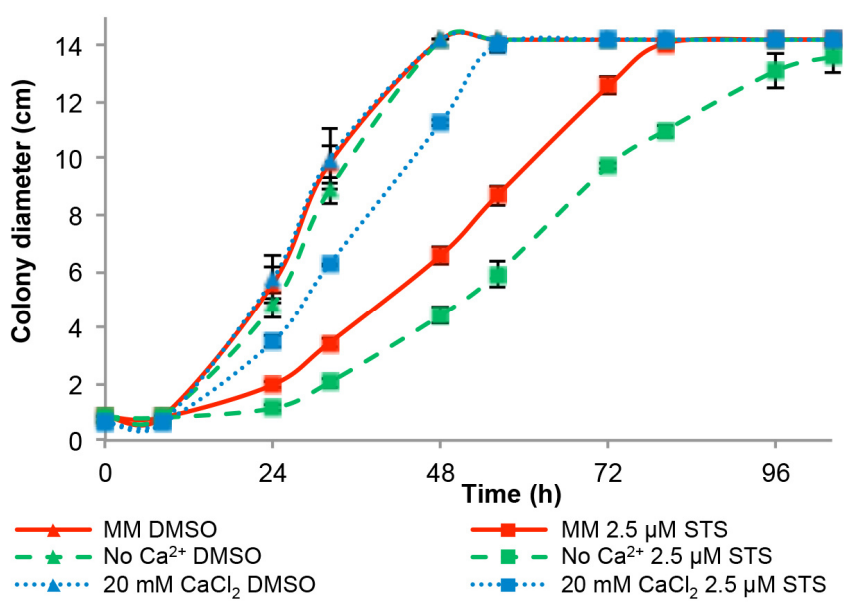

C

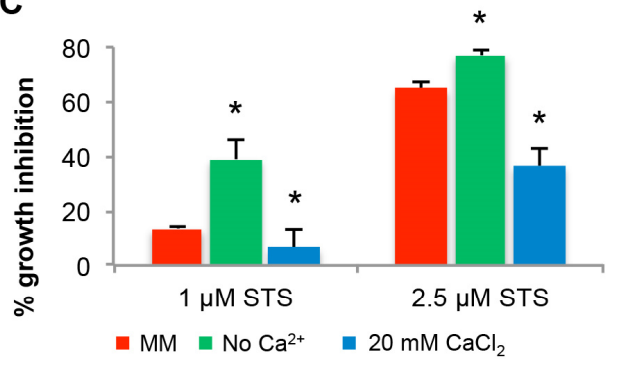

D

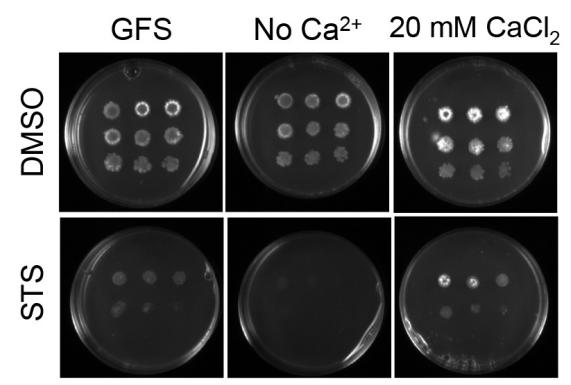

G

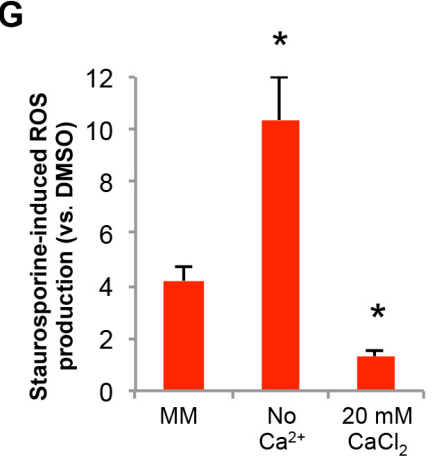

E

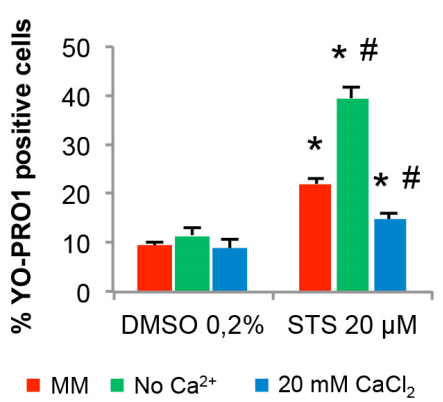

F

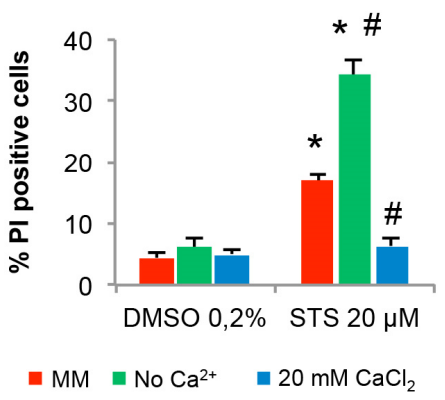

H

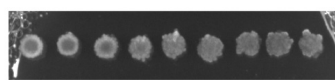

4 mM BAPTA

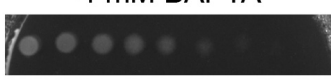

$2.5 \mu \mathrm{M}$ A23187

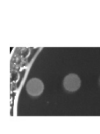

BAPTA + STS

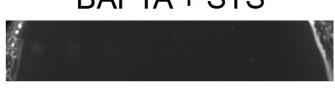

A23187 + STS

STS
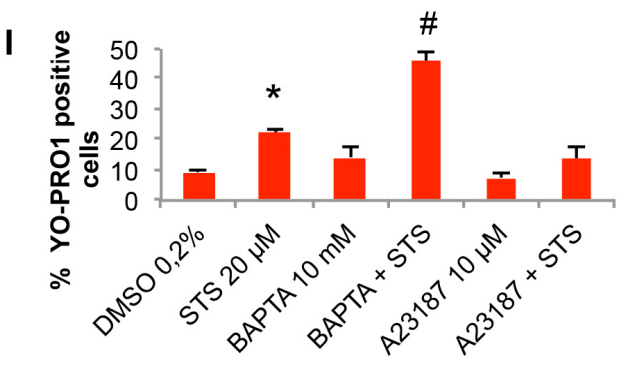

FIGURE 1: Extracellular $\mathrm{Ca}^{2+}$ modulates the $\boldsymbol{N}$. crassa sensitivity to staurosporine. (A-C) Conidia were inoculated on the centre of a Petri dish containing Vogel's MM with $2.5 \mu \mathrm{M}$ staurosporine (STS) and different concentrations of $\mathrm{Ca}^{2+}$. Growth at 32h (A), over time (B) and the percentage of growth in STS-treated cells versus control (C) are shown. Growth rates $(\mathrm{mm} / \mathrm{h})$ are indicated in the left panels in (A). *, pvalue $\leq$ 0.05. (D) Serial dilutions (from left to right) of conidia spotted in GFS agar medium supplemented with $5 \mu M$ STS and different concentrations of $\mathrm{Ca}^{2+}$ were incubated for 3 days. (E-F) Cell death following treatment of the cells with $20 \mu \mathrm{M}$ staurosporine in the indicated liquid culture media was evaluated by flow cytometry quantification of positive cells for YOPRO-1 (E) or PI (F). ${ }^{*}, \mathrm{p}$-value $\leq 0.05$ for the comparison STS versus DMSO in each media; \#, p-value $\leq 0.05$ for the comparison between media after the treatment with STS. (G) The fold increase in cellular ROS accumulation following treatment with $20 \mu \mathrm{M}$ staurosporine in the indicated liquid culture media was evaluated by staining with DHR123. *, p-value $\leq 0.05$. (H-I) Growth inhibition and cell death in $2.5 \mu \mathrm{M}$ STS-treated cells in the presence of BAPTA or A23187 was assessed by spots in GFS medium (H) or cell growth in liquid medium followed by staining with YOPRO-1 (I) *, p-value $\leq 0.05$ for the comparison STS versus DMSO; \#, p-value $\leq 0.05$ for the comparison between STS alone and BAPTA+STS. 
A

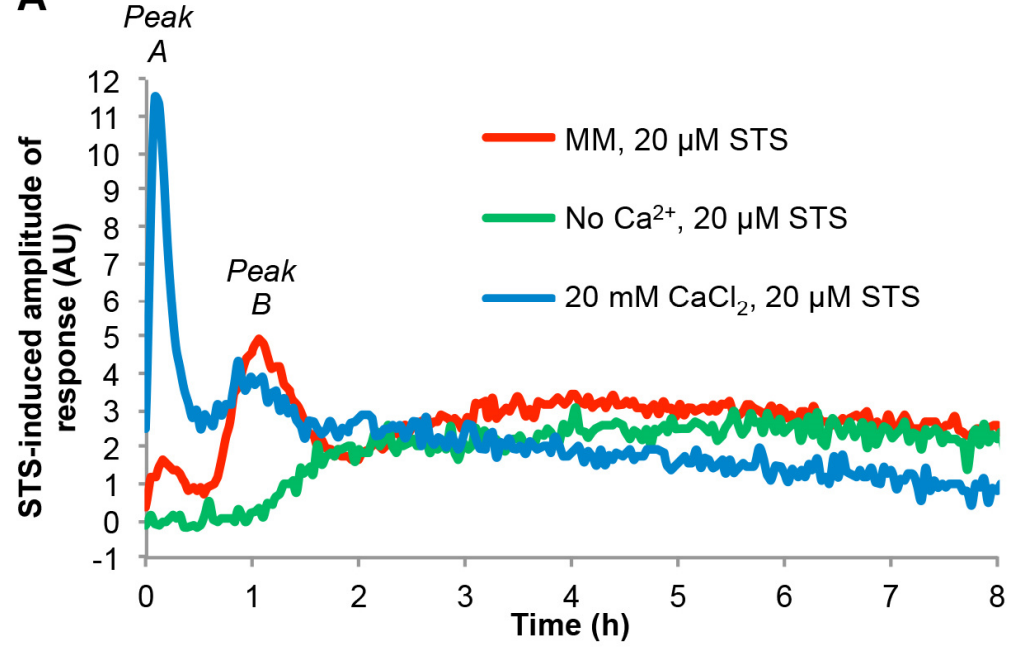

B

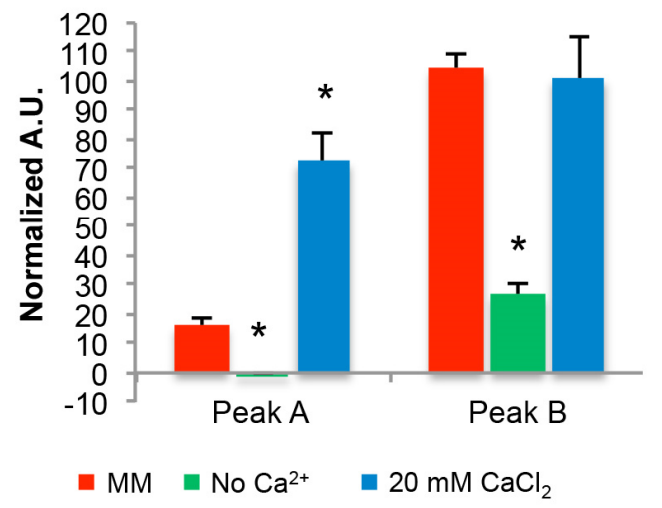

FIGURE 2: Extracellular $\mathrm{Ca}^{2+}$ availability affects intracellular $\mathrm{Ca}^{2+}$ dynamics in response to staurosporine. (A) Aequorin-expressing wild type cells were cultured for 6 hours in the indicated media and after the addition of $20 \mu \mathrm{M}$ staurosporine (STS), luminescence was followed over time. The STS-induced amplitude of response is shown. (B) Quantification (in arbitrary units) of the cytosolic Ca" peaks " $A$ " and " $B$ " (indicated in A). * ${ }^{*}$-value $\leq 0.05$.

synergized whereas elevation of intracellular $\mathrm{Ca}^{2+}$ with A23187 antagonized the effects of staurosporine (Fig. 1H). In agreement, pre-incubation with BAPTA significantly enhanced apoptotic levels induced by staurosporine, whereas they were partially inhibited by $A 23187$, as measured by YOPRO-1 staining (Fig. 11). Altogether, these data consistently indicate that the absence of $\mathrm{Ca}^{2+}$ enhances staurosporine-induced cell death, whereas excess (but not toxic) concentrations of $\mathrm{Ca}^{2+}$ partially prevent it.

Using cells expressing the cytosolic $\mathrm{Ca}^{2+}$ reporter gene aequorin, we described recently that staurosporine induces a three-step $\mathrm{Ca}^{2+}$ response comprising three main signals called " $A$ ", " $B$ " and " $C$ ". Peak " $A$ " occurs immediately after the addition of the drug and lasts approximately 20 minutes; peak " $B$ " appears after 35-40 minutes and lasts approximately 80 minutes; phase " $C$ " is a prolonged and continuous elevation of cytosolic $\mathrm{Ca}^{2+}$ [12]. In the absence of extracellular $\mathrm{Ca}^{2+}$, the $\mathrm{Ca}^{2+}$ response to staurosporine was compromised, with peaks " $A$ " and " $B$ " showing substantial reduction (Fig. 2A-B). In medium with $20 \mathrm{mM} \mathrm{CaCl}_{2}$ there was a strong boost in peak " $A$ ", while peak " $B$ " remained similar to standard MM. These alterations in intracellular $\mathrm{Ca}^{2+}$ dynamics are in agreement with our findings that extracellular $\mathrm{Ca}^{2+}$ uptake is important for the $\mathrm{Ca}^{2+}$ signaling response to staurosporine [12].

Distinct transcriptional programs in staurosporine-treated cells depend on the extracellular $\mathrm{Ca}^{2+}$ availability

Treatment with $20 \mu \mathrm{M}$ staurosporine led to significant alterations in the expression of $\sim 28 \%$ of the $N$. crassa genes (1921 genes) [15]. The extent of this transcriptional response was amplified in the absence of $\mathrm{Ca}^{2+}(\sim 36 \%$ of genes ( 2749 genes) were altered by the drug), and markedly suppressed by $20 \mathrm{mM}$ of $\mathrm{CaCl}_{2}$ ( $6 \%$ genes ( 454 genes) showed altered profiles) (Fig. 3A-B). In standard medium, approximately half of the genes were induced and approximately half were repressed by staurosporine [15]. In no $\mathrm{Ca}^{2+}$ medium, $43.1 \%$ of the altered genes were upregulated, whereas $56.9 \%$ where downregulated. Remarkably, in the presence of excessive $\mathrm{Ca}^{2+}$ most of the altered genes were repressed ( $68 \%)$. The complete dataset obtained from these RNA-seq experiments is presented as File S1.

We analysed the distribution of the individual genes induced and repressed by staurosporine in the different culture media. In the absence of $\mathrm{Ca}^{2+}, 792$ (66.8\%) of the induced genes were specific to this condition while in $20 \mathrm{mM}$ $\mathrm{CaCl}_{2}$ this corresponded to 67 (46.2\%) genes (Fig. 3C and File S1). Among repressed genes, 875 (56.0\%) and 157 (50.8\%) genes were specific to no $\mathrm{Ca}^{2+}$ and $20 \mathrm{mM} \mathrm{CaCl}_{2}$ media, respectively (Fig. 3D and File S1). Only minor fractions of the altered genes ( 30 and 74 genes, induced and repressed, respectively) were common to all conditions.

FunCat was used to examine the enrichment of functional categories in the different gene sets (File S2; Table $\mathrm{S} 1-\mathrm{S} 2)$. The most interesting $\mathrm{Ca}^{2+}$ concentration-specific differences were found among the downregulated genes. In the absence of $\mathrm{Ca}^{2+}$, staurosporine led to the downregulation of genes included in numerous categories. These encompass various groups within the 'Metabolism' supercategory such as 'metabolism of the aspartate family', 'purine nucleotide/nucleoside/nucleobase metabolism', 'phosphate metabolism' and 'tetracyclic and pentacyclic triterpenes metabolism'. Also, there was a specific repression of genes involved in 'Cell cycle and DNA processing' and 'Transcription', namely 'mRNA synthesis' and 'mRNA processing'. Categories related to stress responses like 'Protein fate', 'unfolded protein response', 'cellular sensing and response to external stimulus', 'cell growth', 'antiapoptosis' were also repressed. Finally, while in standard MM there was a downregulation of 'aerobic respiration' 
A

i

No $\mathrm{Ca}^{2+}$ :

DMSO vs STS

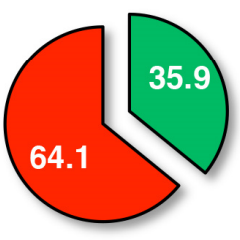

$\square$ Yes $\square$ No ii

No $\mathrm{Ca}^{2+}$ :

DMSO vs STS

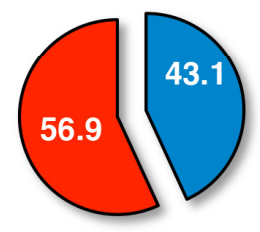

口Up םDown
B

i

ii

$20 \mathrm{mM} \mathrm{CaCl}$
DMSO vs STS

DMSO vs STS

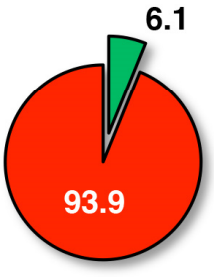

$\square$ Yes $\square$ No

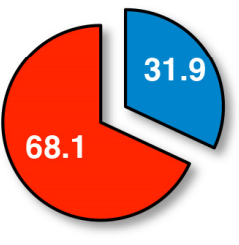

口Up םDown

C
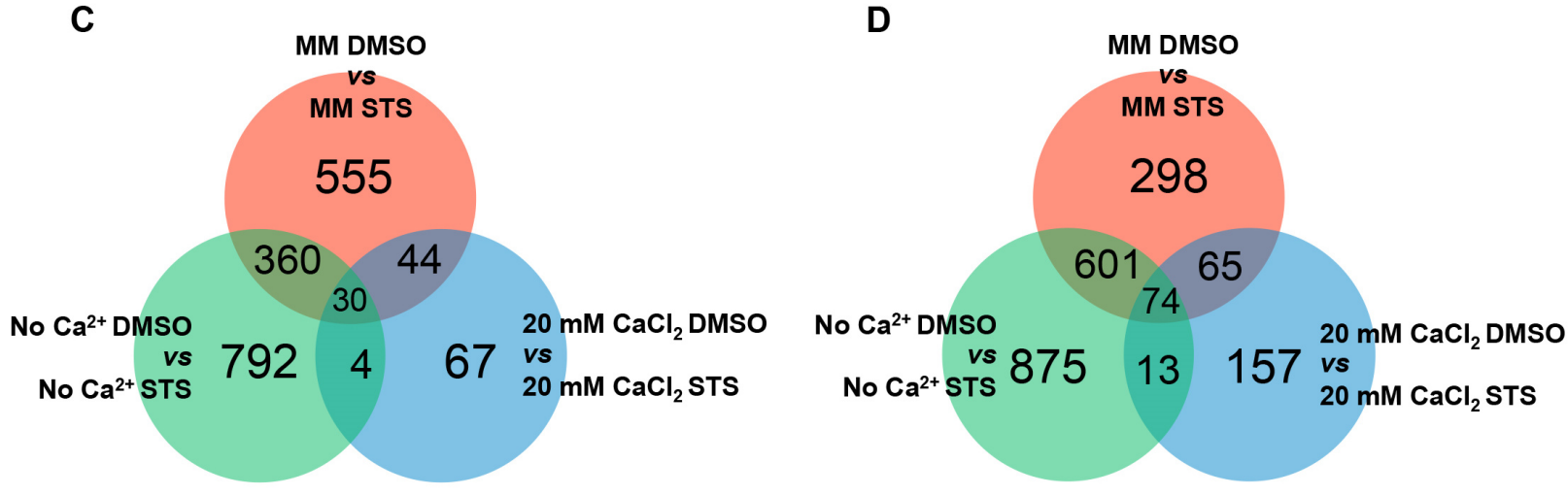

FIGURE 3: Overview of the $N$. crassa transcriptional response to staurosporine in minimal media containing different concentrations of $\mathrm{Ca}^{2+}$. (A-B) The percentages of genes with altered expression upon treatment with staurosporine (i) and the fraction of induced and repressed genes (ii) were calculated for culture medium with no $\mathrm{Ca}^{2+}$ (A) or with $20 \mathrm{mM} \mathrm{CaCl}_{2}$ (B). (C-D) Venn diagrams were used to assess the amount of $\mathrm{Ca}^{2+}$-specific staurosporine-induced (C) and -repressed genes (D). General statistics for $\mathrm{Ca}^{2+}$-specific transcriptional responses are included.

genes, in no $\mathrm{Ca}^{2+}$ medium, other bioenergetic pathways were repressed: 'glycolysis and gluconeogenesis' and 'pentose-phosphate pathway'. These data indicates that a highly complex transcriptional program is established by staurosporine-treated cells growing in the absence of $\mathrm{Ca}^{2+}$ resulting in the repression of several genes related with an anti-stress response. It seems that, when $\mathrm{Ca}^{2+}$ is limited, staurosporine causes the downregulation of cellular de- fences and this may be related to the high susceptibility of these cells to the drug.

RNA-seq analysis of the fungal reaction to staurosporine revealed that the drug can trigger very distinct transcriptional responses depending on the concentrations of $\mathrm{Ca}^{2+}$ in the culture medium. This is probably associated with the observed differences in the levels of staurosporine-induced cell death in the three media.
A

i

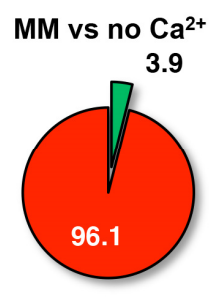

aYes $\square$ No
$\mathrm{MM}$ vs no $\mathrm{Ca}^{2+}$

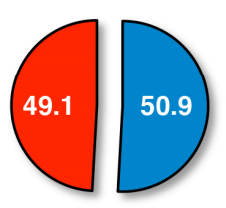

口Up aDown
B

i

$M M$ vs $20 \mathrm{mM} \mathrm{CaCl}{ }_{2} \quad M M$ vs $20 \mathrm{mM} \mathrm{CaCl}$

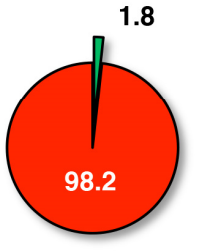

aYes $\square$ No

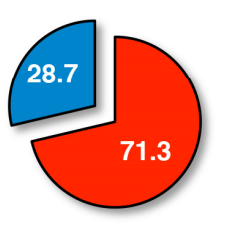

口Up םDown
FIGURE 4: Overview of the $N$. crassa transcriptional response to limited or excess $\mathrm{Ca}^{2+}$. (A-B) The percentages of genes with altered expression (i) and the fraction of induced and repressed genes (ii) were calculated for no $\mathrm{Ca}^{2+}(\mathrm{A})$ and $20 \mathrm{mM} \mathrm{CaCl} 2$ medium (B) in comparison with standard MM. 
A

\begin{tabular}{lll}
\multicolumn{3}{l}{ No $\mathrm{Ca}^{2+}$ upregulated genes (139) } \\
\hline ID & Category & P-value \\
\hline 01.01 & $\begin{array}{l}\text { amino acid metabolism } \\
\text { nitrogen, sulfur and }\end{array}$ & $3.52 \mathrm{E}-06$ \\
02.13 .01 & anaerobic respiration & $3.95 \mathrm{E}-08$ \\
20.01 .01 .01 & cation transport & 0.002958 \\
20.01 .01 .07 & anion transport & $2.19 \mathrm{E}-05$ \\
20.03 & transport facilities & $1.29 \mathrm{E}-05$ \\
20.09 .18 .07 & non-vesicular cellular import & $3.39 \mathrm{E}-07$ \\
32.01 .04 & pH stress response & 0.001205 \\
34.01 .01 & homeostasis of cations & 0.000272 \\
34.01 .03 & homeostasis of anions & $4.92 \mathrm{E}-05$ \\
\hline
\end{tabular}

$20 \mathrm{mM} \mathrm{CaCl}{ }_{2}$ upregulated genes (88)

\begin{tabular}{lll}
\hline ID & Category & P-value \\
\hline 02.11 & $\begin{array}{l}\text { electron transport and membrane- } \\
\text { associated energy conservation }\end{array}$ & 0.000179 \\
02.11 .05 & $\begin{array}{l}\text { accessory proteins of electron transport and } \\
\text { membrane-associated energy conservation }\end{array}$ & 0.002529 \\
02.13 & respiration & 0.000695 \\
20.09 .18 .07 & non-vesicular cellular import & $9.84 \mathrm{E}-07$ \\
\hline
\end{tabular}

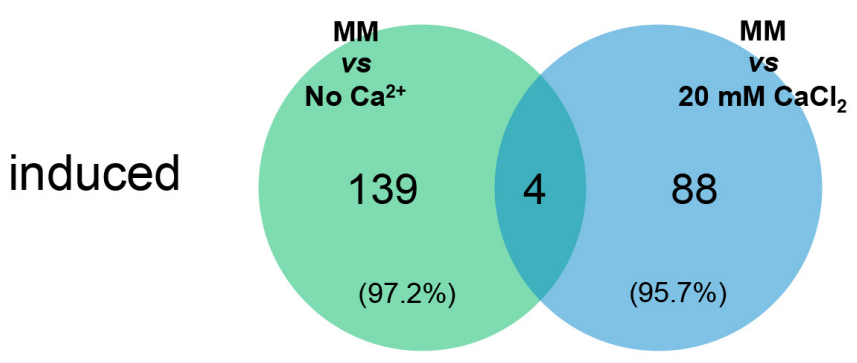

B

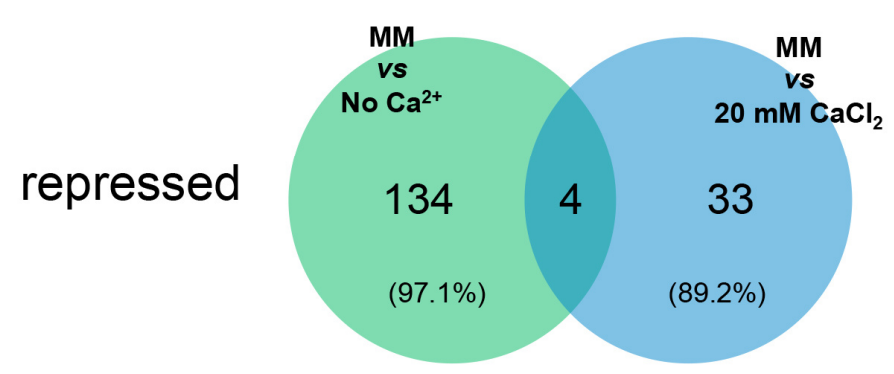

No $\mathrm{Ca}^{2+}$ downregulated genes (134)

\begin{tabular}{lll}
\hline ID & Category & P-value \\
\hline 20.03.02.03.01 & proton driven antiporter & 0.001853 \\
\hline
\end{tabular}

$20 \mathrm{mM} \mathrm{CaCl}{ }_{2}$ downregulated genes (33)

\begin{tabular}{lll}
\hline ID & Category & P-value \\
\hline 20.01 .01 .01 & cation transport & $3.50 \mathrm{E}-05$ \\
20.01 .01 .07 & anion transport & $2.61 \mathrm{E}-06$ \\
32.01 .04 & $\mathrm{pH}$ stress response & $1.66 \mathrm{E}-07$ \\
34.01 .01 & homeostasis of cations & $7.25 \mathrm{E}-07$ \\
34.01 .03 & homeostasis of anions & $1.80 \mathrm{E}-07$ \\
\hline
\end{tabular}

FIGURE 5: Functional enrichment analysis of the transcriptional alterations caused by limited or excess $\mathrm{Ca}^{2+}$. (A-B) The transcriptional response to the absence or excess of $\mathrm{Ca}^{2+}$ was investigated by building Venn diagrams showing the distribution of genes with induced (A) or repressed (B) expression in no $\mathrm{Ca}^{2+}$ and $20 \mathrm{mM} \mathrm{CaCl}_{2}$ medium. Lists of enriched categories are included. 
Limited and excess of $\mathrm{Ca}^{2+}$ alters basal gene expression The transcriptional response to the lack or excess of $\mathrm{Ca}^{2+}$ was analysed by comparing basal gene expression in no $\mathrm{Ca}^{2+}, 20 \mathrm{mM} \mathrm{CaCl}_{2}$ and standard MM (File S3). The fraction of genes with altered expression in no $\mathrm{Ca}^{2+}$ and $20 \mathrm{mM}$ $\mathrm{CaCl}_{2}$ compared with standard $\mathrm{MM}$ was $3.9 \%$ and $1.8 \%$, respectively (Fig. 4A-B), corresponding to 281 and 129 genes, respectively. While half of the genes altered in no $\mathrm{Ca}^{2+}$ were induced and half were repressed, in $20 \mathrm{mM} \mathrm{CaCl}_{2}$ most of the altered genes were upregulated (71.3\%). Most of the genes were specifically induced or repressed depending on the particular culture medium: $97.2 \%$ and 97.1\%, respectively, for no $\mathrm{Ca}^{2+}$, and $95.7 \%$ and $89.2 \%$, respectively, for $20 \mathrm{mM} \mathrm{CaCl}_{2}$ (Fig. 5A-B). Not surprisingly, categories related to 'ion transport', 'homeostasis of cations' and 'homeostasis of anions' were enriched in the set of genes induced in the absence of $\mathrm{Ca}^{2+}$ (Fig. 5A and File S4), which is perhaps linked to a cellular attempt to recover proper conditions of osmolarity. Consistently, these categories were also significantly enriched among the genes repressed in the presence of $20 \mathrm{mM} \mathrm{CaCl}_{2}$ (Fig. 5B). Lack of $\mathrm{Ca}^{2+}$ also seems to be associated to a metabolic adaptation of the cells, since there was enrichment in the induction of genes falling on the 'metabolism' super-category, like 'amino acid metabolism', 'nitrogen, sulfur and selenium metabolism' and 'anaerobic respiration'.

We looked for alterations in the expression of known $\mathrm{Ca}^{2+}$ channels, $\mathrm{Ca}^{2+}$-ATPases, $\mathrm{Ca}^{2+}$-exchangers, $\mathrm{Ca}^{2+}$ dependent signaling molecules and other $\mathrm{Ca}^{2+}$ binding proteins [18, 19, 31, 32] (Fig. S1 and File S5). NCU11680, NCU04736 and NCU07075, encoding the TRP channel YVC1, the $\mathrm{Ca}^{2+}$-ATPase NCA-2 and the $\mathrm{Ca}^{2+} / \mathrm{H}^{+}$antiporter CAX, respectively, were repressed in the absence of $\mathrm{Ca}^{2+}$. NCU04265, encoding the invertase enzyme (INV) was induced in the absence of $\mathrm{Ca}^{2+}$. The induction of INV, an enzyme that hydrolyses extracellular sucrose into glucose and fructose, is a marker of the process of carbon catabolite repression [33, 34]. NCU08147, encoding the stress-related $\mathrm{Ca}^{2+}$-ATPase ENA-2 [35] was repressed in the presence of $20 \mathrm{mM} \mathrm{CaCl}$. NCU05046 and NCU07966, encoding ENA-1 and TRM-1, respectively, were induced by no $\mathrm{Ca}^{2+}$ and repressed in $20 \mathrm{mM} \mathrm{CaCl}_{2}$ medium. These results further suggest an intracellular metabolic remodeling in response to $\mathrm{Ca}^{2+}$ availability.

Two putative novel components of the $\mathrm{N}$. crassa $\mathrm{Ca}^{2+}$ homeostasis machinery

We found that 188 genes with unknown function ("hypothetical proteins") had altered expression in no $\mathrm{Ca}^{2+}$ or in $20 \mathrm{mM} \mathrm{CaCl}_{2}$ medium. We screened the respective protein sequences for the presence of $\mathrm{Ca}^{2+}$-binding patterns using CaPS [20] and identified 6 candidates (NCU01697, NCU08524, NCU06116, NCU07582, NCU06607 and NCU03647). We further considered NCU08524 and NCU06607, because the others did not display convincing similarities with known proteins, even around the predicted $\mathrm{Ca}^{2+}$-binding motif. NCU08524 was repressed in $\mathrm{Ca}^{2+}$ free medium whereas NCU06607 was induced by $20 \mathrm{mM}$ $\mathrm{CaCl}_{2}$ (Fig. 6A). Fig. 6B shows the alignment of the predict- ed $\mathrm{Ca}^{2+}$-binding motifs of NCU08524 and NCU06607 with those of proteins containing the Dx[DN]xDG motif $[22,23]$. The NCU08524 motif sequence resembles that of the rhamnogalacturonan lyase YesW from Bacillus subtilis. YesW exemplifies $\beta$-propeller structures in which the Dx[DN]xDG motif can be embedded in one of the propeller blades, forming a 'calcium blade' structure [22]. Such a calcium blade was recently described in a fungal lectin from Psathyrella velutina [22]. NCU08524 is similar to a fucose-specific lectin from Macrophomina phaseolina (Table S3) and matches from HHpred suggest that it contains a 6 -bladed propeller structure in which $\beta$-strands flank the putative $\mathrm{Ca}^{2+}$-binding motif. Taking advantage of the similarity between fucose-specific lectins and NCU08524, molecular models were built for the latter in a situation of $\mathrm{Ca}^{2+}$ binding (Fig. S2A-C). In proteins containing the Dx[DN]xDG motif, interactions with bound $\mathrm{Ca}^{2+}$ ions are supplemented by the interaction of side chains from at least one downstream acidic residue [22]. Therefore, three molecular models were prepared, considering $\mathrm{Glu}^{502}$, Glu $\mathrm{G}^{503}$ or $\mathrm{Asp}^{504}$ as the possible additional acidic residue. The models show that NCU08524 can accommodate a $\mathrm{Ca}^{2+}$-binding geometry by combining the $D x[D N] \times D G$ motif with any of these downstream residues (Fig. S2A-C).

The predicted $\mathrm{Ca}^{2+}$-binding motif of NCU06607 (Fig. 6C) is comparable to the Dx[DN]xDG motif of a calmodulin from Paramecium tetraurelia [23]. Molecular modeling of NCU06607 was not feasible because the Dx[DN]xDG motif is not located within a folded domain of known structure, but at the beginning of a predicted intrinsically disordered region. Anyway, the Dx[DN]xDG motif is sometimes found in highly disordered regions [36]. NCU06607 has a predicted extracellular localization and there is a strong bias in the localization of proteins possessing the Dx[DN]xDG motif towards the cell surface or secretion [22]. Plasma membrane localization together with a transmembrane domain was predicted for NCU08524 (Table S3).

The growth of $\triangle \mathrm{NCU} 08524$ and $\triangle \mathrm{NCU} 06607$ was compared with the wild type strain under different conditions of $\mathrm{Ca}^{2+}$ availability. The growth of both mutants was significantly reduced in no $\mathrm{Ca}^{2+}$ medium and in medium containing the $\mathrm{Ca}^{2+}$ chelator BAPTA (Fig. 6D). $\triangle \mathrm{NCU} 06607$ also showed a significant reduction in growth in the presence of $20 \mathrm{mM} \mathrm{CaCl}_{2}$ as compared with wild type. The observed differences in growth were not merely due to non-specific osmotic stress, since all strains were similarly affected by the addition of $4 \% \mathrm{NaCl}$. $\triangle \mathrm{NCU} 06607$ was slightly more sensitive to staurosporine than wild type, suggesting that the respective protein may be involved in the response to the drug (Fig. 6E). In summary, the RNA-seq dataset and further analysis revealed two putative novel components of the $\mathrm{Ca}^{2+}$-handling machinery in N. crassa.

Several members of the $\mathrm{Ca}^{2+}$ homeostasis machinery are involved in the fungal response to staurosporine

To further substantiate the crucial role of $\mathrm{Ca}^{2+}$ during the $N$. crassa response to staurosporine and to identify mediators of the process, we assayed the drug sensitivity profile of approximately 50 deletion strains encoding proteins in- 
volved in $\mathrm{Ca}^{2+}$ homeostasis. We showed recently that deletion of genes encoding phospholipase $C$ enzymes, especially $\mathrm{PLC}-2$, results in mutants resistant to staurosporine, while strains lacking the $\mathrm{Ca}^{2+}$ channels $\mathrm{CCH}-1$ and MID-1 are hypersensitive [12]. Several other deletion strains that lack $\mathrm{Ca}^{2+}$-permeable channels, $\mathrm{Ca}^{2+}$-ATPases or other $\mathrm{Ca}^{2+}$ binding molecules involved in cellular signaling showed a resistance phenotype to staurosporine that was dissimilar from the wild type strain (Fig. 7). A resistance phenotype was particularly strong in deletion mutants for genes encoding the $\mathrm{Ca}^{2+}$-ATPases NCA-2 and PMR-1, and deletion of other $\mathrm{Ca}^{2+}$-ATPases, namely ENA-1, ENA-2 and NCU10143 also led to increased resistance. The disruption of the signaling molecules calmodulin, CAMK-4, and CSE-1 aug-
A

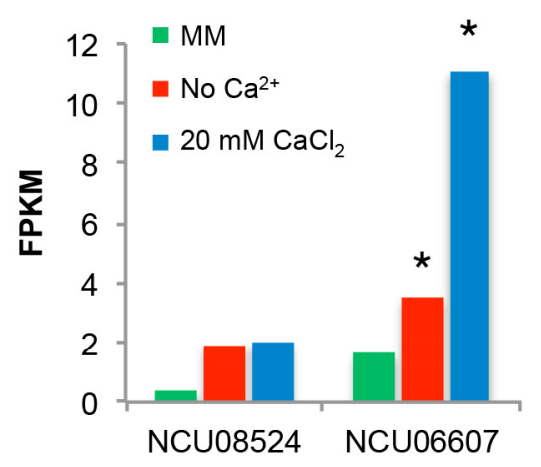

B

YesW [B. subtilis] 148 T Y S A NDA S V GDVDGDGQY E L /L KWDPSN S KDN SQ 181

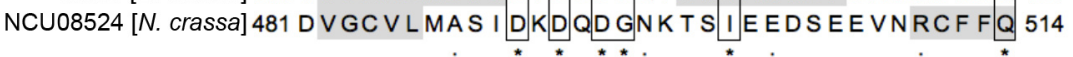

C

Calmodulin [P. tetraurelia] 10 AEF KE A FA LFDKDGDGT I TTKE LGTVMRS LGQNP 43 NCU06607 [N. crassa] 198 VTKEE I LAAFDVDED D L L RRAEDTCEDDGTPDDA 232 $* * * * * * * *$ : ${ }_{*}$

D

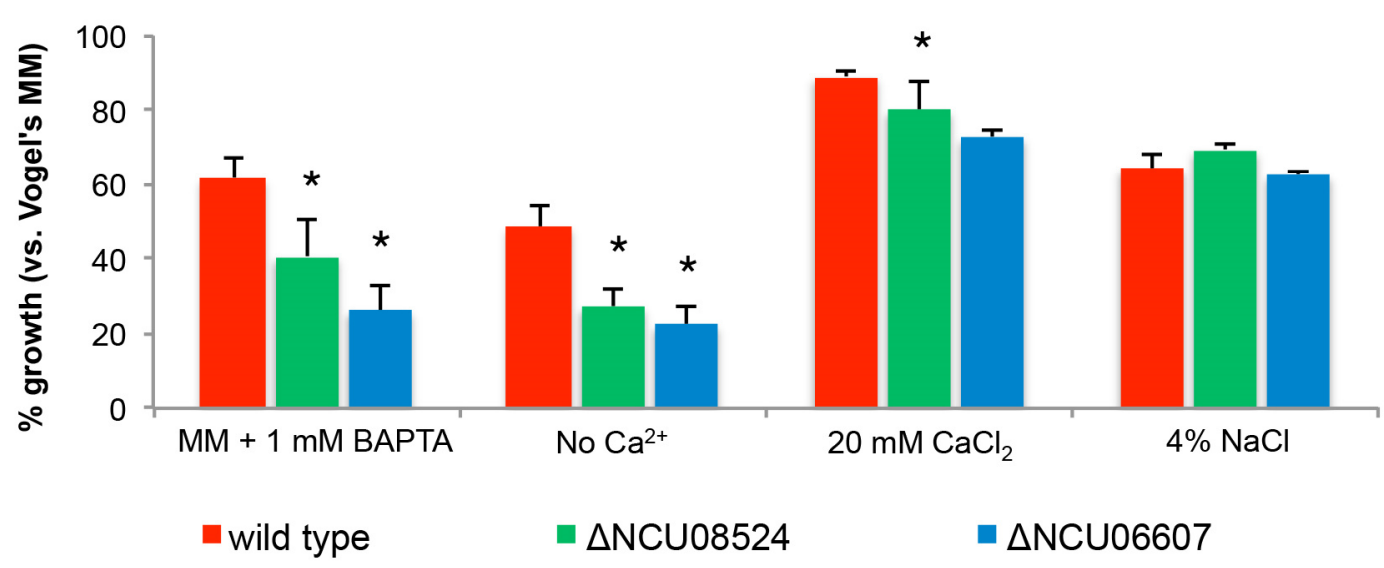

E

DMSO

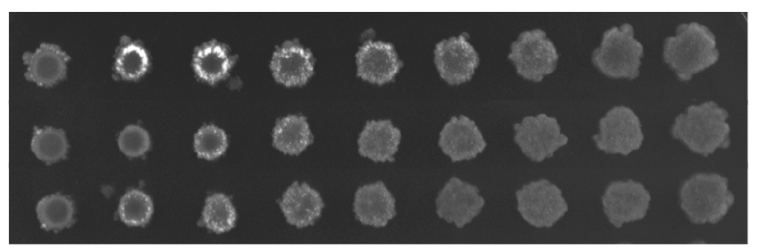

STS

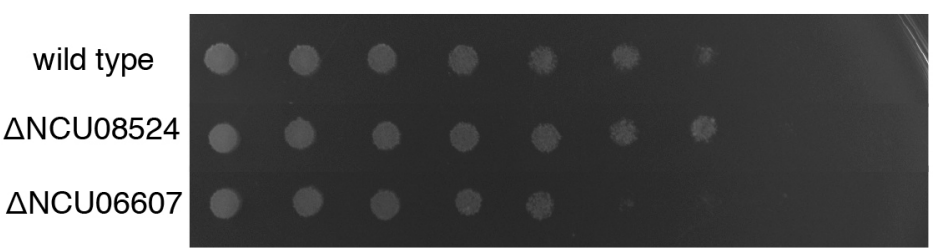

FIGURE 6: Identification of putative novel $\mathrm{Ca}^{2+}$-binding proteins. (A) Expression levels of NCU08524 and NCU06607 in no $\mathrm{Ca}^{2+}$, standard $\mathrm{MM}$ and $20 \mathrm{mM} \mathrm{CaCl}_{2}$ media. *, p-value $\leq 0.05$. (B-C) Sequence alignments of the EF-hand-like domain of NCU08524 and YesW from B. subtilis (accession number: 031526; PDB code: 2z8r) (B), and NCU06607 and calmodulin from P. tetraurelia (accession number: P07463; PDB code: 1exr) (C). Residues binding $\mathrm{Ca}^{2+}$ in YesW and calmodulin are in bold; $\beta$-strands and $\alpha$-helices are shaded in light and dark grey, respectively (confirmed by crystallography for YesW [61] and calmodulin [62] and predicted with MEMSAT3 for NCU08524 and NCU06607). (D) The percentages of growth of the different strains in the indicated media versus standard MM were determined by measuring absorbance of the respective liquid cultures at $450 \mathrm{~nm}$. ${ }^{*}, \mathrm{p}$-value $\leq 0.05$. (E) The spot assay was used to examine the sensitivity of $\triangle N C U 08524$ and $\triangle N C U 06607$ to $5 \mu \mathrm{M}$ staurosporine (STS). 
DMSO
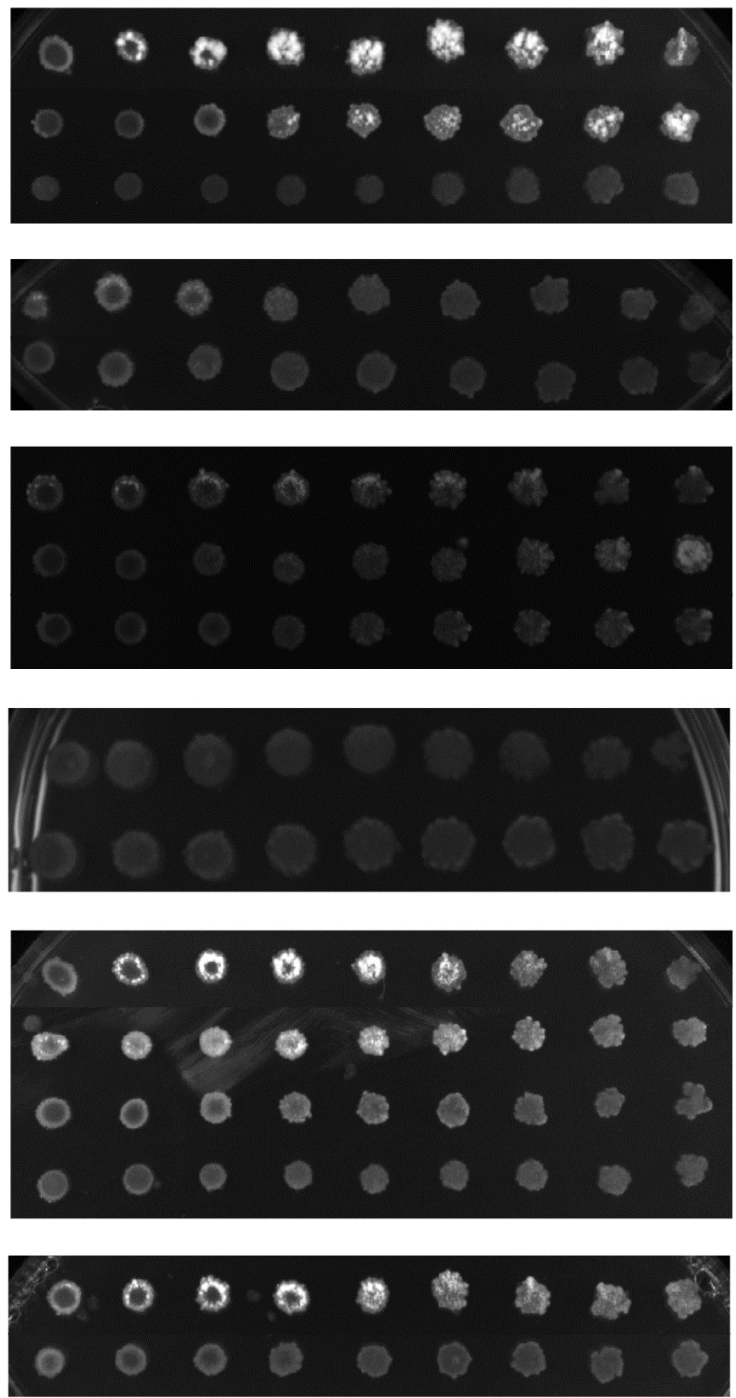

STS

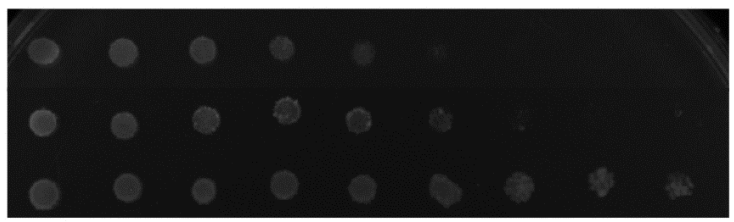

wild type

$\Delta$ ena-2

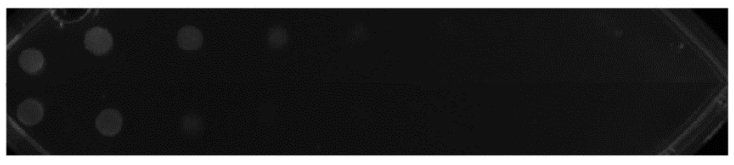

wild type

$\triangle N C U 10143$

$\triangle N C U 03750$

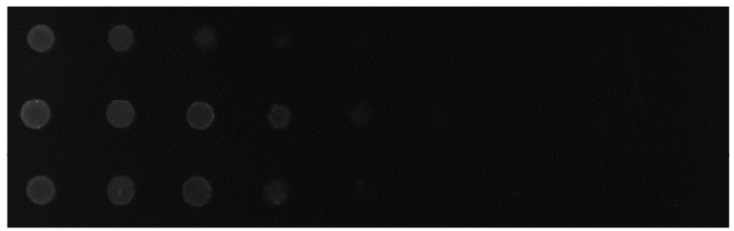

wild type

$\Delta p m r-1$

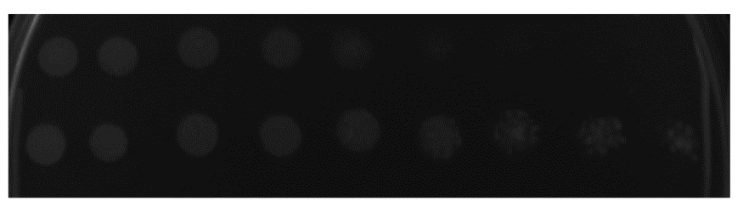

wild type

$\Delta$ camk-4

$\Delta p r d-4$

$\Delta c s e-1$

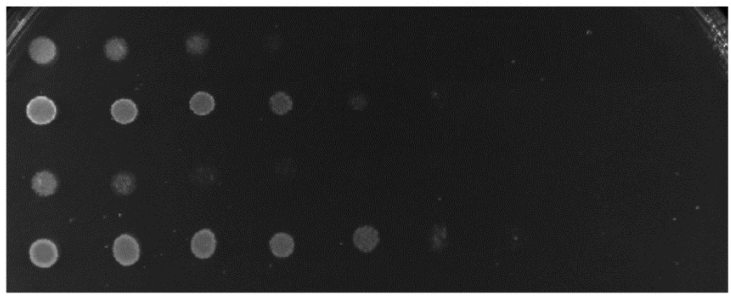

wild type

$\Delta s t k-16$

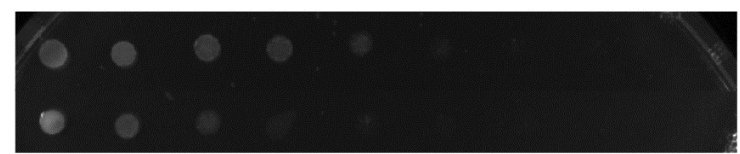

FIGURE 7: Several members of the $\mathrm{Ca}^{2+}$ handling machinery are involved in the fungal response to staurosporine. Serial dilutions (from left to right) of conidia from the indicated strains were spotted on GFS medium supplemented with $5 \mu \mathrm{M}$ staurosporine (STS) and incubated for 3 days.

mented resistance, whereas strains carrying deletions in genes encoding STK-16 and PRD-4 resulted in increased susceptibility to staurosporine. Table 1 lists strains with altered sensitivity to staurosporine and Table S4 lists all strains tested. The deletion strains for NCU05360, NCU03804, NCU03833, NCU09871, NCU06347, NCU06617, NCU02411 and NCU09265 were not tested due to strain unavailability or their heterokaryotic nature. This data further stresses the importance and complexity of the fungal response to staurosporine, implicating numerous $\mathrm{Ca}^{2+}$ related proteins of different function and subcellular localization in the process.

\section{DISCUSSION}

Here we show that controlling the amount of $\mathrm{Ca}^{2+}$ available in the extracellular milieu is enough for a robust modula- tion of the effects of staurosporine in $N$. crassa. Cell death is strongly enhanced by $\mathrm{Ca}^{2+}$ limitation whereas it is partially suppressed by a $\sim 30$-fold excess of external $\mathrm{Ca}^{2+}$. A similar behavior was observed in S. cerevisiae cells treated with miconazole or terbinafine, inhibitors of ergosterol biosynthesis [37], suggesting common stress-responsive pathways in the two fungi, even when the stimuli have apparently distinct targets. Supplementation of the medium with high $\mathrm{Ca}^{2+}$ concentrations ( $20 \mathrm{mM} \mathrm{CaCl}$, as used here) protected $N$. crassa cells from toxicity induced by PAF, an antifungal protein from Penicillium chrysogenum that also disturbs intracellular $\mathrm{Ca}^{2+}$ homeostasis [10]. Our results substantiate the view that $\mathrm{Ca}^{2+}$ is an important player during cell death.

The effects of staurosporine in media containing different amounts of $\mathrm{Ca}^{2+}$ are remarkably paralleled by distinct 
TABLE 1. Strains with $\mathrm{Ca}^{2+}-$ related deleted genes that exhibit altered sensitivity to staurosporine when compared with wild type $\mathrm{N}$. crassa.

\begin{tabular}{|c|c|c|c|}
\hline Strain & Gene name & Classification [17-19] & Phenotype \\
\hline$\triangle N C U 02762$ & cch-1 & $\mathrm{Ca}^{2+}$-permeable channel & SS [12] \\
\hline$\triangle N C U 06703$ & mid-1 & $\mathrm{Ca}^{2+}$-permeable channel & SS [12] \\
\hline$\triangle N C U 04736$ & $n c a-2$ & $\mathrm{Ca}^{2+}$-ATPase & $\mathrm{RR}$ \\
\hline$\triangle N C U 05046$ & ena-1 & $\mathrm{Ca}^{2+}$-ATPase & $\mathrm{R}$ \\
\hline$\triangle N C U 08147$ & ena-2;ph-7 & $\mathrm{Ca}^{2+}$-ATPase & $S$ \\
\hline$\triangle N C U 10143$ & & $\mathrm{Ca}^{2+}$-ATPase & $\mathrm{R}$ \\
\hline$\triangle N C U 03292$ & $p m r-1$ & $\mathrm{Ca}^{2+}$-ATPase & $\mathrm{RR}$ \\
\hline$\triangle N C U 06245$ & $p / c-1$ & Phospholipase C ( $\delta$-type) & $\mathrm{R}[12]$ \\
\hline$\triangle N C U 01266$ & plc-2 & Phospholipase C ( $\delta$-type) & $\mathrm{RR}[12]$ \\
\hline$\triangle N C U 09655$ & plc-3 & Phospholipase C ( $\delta$-type) & $\mathrm{R}[12]$ \\
\hline$\triangle N C U 03750$ & & Calmodulin & $\mathrm{R}$ \\
\hline$\triangle N C U 04379$ & cse-1 & $\mathrm{Ca}^{2+}$ and/or CaM binding protein & $\mathrm{R}$ \\
\hline$\triangle N C U 09212$ & camk-4 & $\mathrm{Ca}^{2+}$ and/or CaM binding protein & $\mathrm{R}$ \\
\hline$\triangle N C U 00914$ & $s t k-16$ & $\mathrm{Ca}^{2+}$ and/or CaM binding protein & $S$ \\
\hline$\triangle N C U 02814$ & prd-4 & $\mathrm{Ca}^{2+}$ and/or CaM binding protein & $S$ \\
\hline
\end{tabular}

SS: much more sensitive; S: slightly more sensitive; RR: much more resistant; R: slightly more resistant.

cytosolic $\mathrm{Ca}^{2+}$ dynamics, in line with our previous findings that extracellular $\mathrm{Ca}^{2+}$ uptake is required for the development of the cytosolic $\mathrm{Ca}^{2+}$ signature induced by staurosporine [12]. We have recently demonstrated that during the staurosporine-induced $\mathrm{Ca}^{2+}$ signature, peaks " $A$ " and " $\mathrm{B}$ " precede cell death, suggesting that they represent signaling events. In the presence of $20 \mathrm{mM} \mathrm{CaCl}_{2}$ the peak " $\mathrm{A}$ " is enhanced, whereas in medium lacking $\mathrm{Ca}^{2+}$ peaks " $A$ " and " $\mathrm{B}$ " of the staurosporine-induced cytosolic $\mathrm{Ca}^{2+}$ response are abolished. Thus, intracellular $\mathrm{Ca}^{2+}$ signaling that is triggered by staurosporine is markedly modulated by the concentration of $\mathrm{Ca}^{2+}$ in the external medium and might have a role in determining cell survival. However, the intracellular response to staurosporine is very complex and direct conclusions on the susceptibility of the cells based solely on the cytosolic $\mathrm{Ca}^{2+}$ profile, although tempting, are not possible. For instance, a $\Delta p / c-2$ mutant shows increased resistance to the drug despite that its cytosolic $\mathrm{Ca}^{2+}$ response to staurosporine is nearly obliterated [12]. Thus, it seems that events downstream of the cytosolic changes in $\mathrm{Ca}^{2+}$ levels ultimately define cell fate in response to staurosporine.

The screening for staurosporine sensitivity of $\mathrm{Ca}^{2+}$ handling mutant strains revealed a number of proteins likely involved in the cell death response to the drug. Further studies are needed to contextualize them functionally in the mechanism of action of the drug. NCA-2 is a Ca ${ }^{2+}$ ATPase which pumps excess of cytosolic $\mathrm{Ca}^{2+}$ to the vacuoles or extracellular space $[38,39]$, and the respective knockout cells are very resistant to staurosporine. The knockout strain for PMR-1, a Golgi-localized $\mathrm{Ca}^{2+}$-ATPase [40], is also very resistant to staurosporine and yeast $\triangle P M R 1$ knockout cells accumulate much less $\mathrm{Ca}^{2+}$ in the ER
[41]. Lack of these functions in $\Delta n c a-2$ and $\Delta p m r-1$ cells is likely related to the phenotype of the strains upon treatment with staurosporine, as both the ER and the vacuoles play an important role during the fungal response to staurosporine [12]. It is plausible that the lack of NCA-2 or PMR-1 results in an increased accumulation of $\mathrm{Ca}^{2+}$ in the cytosol and this is consistent with the observations that high levels of $\mathrm{Ca}^{2+}$ (below a toxicity threshold) protect against the effects of staurosporine. The lack of NCA-2 has been recently associated with increased sensitivity to UV exposure, further implicating the molecule in cell survival [42]. Other $\mathrm{Ca}^{2+}$-related deletion strains present altered resistance to staurosporine, including $\Delta c s e-1, \Delta c a m k-4$ and $\Delta s t k-16$. Knockout of cse-1 has been shown to lead to impaired germling communication and fusion [43], as well as increased sensitivity to UV irradiation and $\mathrm{Ca}^{2+}[44]$. A previous study has shown that disruption of camk-4 results in benomyl resistance, while disruption of $s t k-16$ leads to increased sensitivity to fludioxonil, sodium chloride and benomyl [45].

The $N$. crassa transcriptional response to staurosporine is robustly reduced in the presence of $20 \mathrm{mM} \mathrm{CaCl}_{2}$ when compared with standard MM, whereas limited extracellular $\mathrm{Ca}^{2+}$ causes alterations in an increased number of genes. Thus, different concentrations of extracellular $\mathrm{Ca}^{2+}$ not only lead to distinct intracellular $\mathrm{Ca}^{2+}$ dynamics, ROS accumulation and cell death levels, but also seem to be coupled to unique transcriptional profiles. It appears that, in the absence of $\mathrm{Ca}^{2+}$, cells treated with staurosporine turn off a diverse array of biological processes. We discovered several enriched functional categories in the set of no $\mathrm{Ca}^{2+}$ medium-specific repressed genes, including the repression of genes involved in cell cycle, signal transduction, cell growth, 
anti-apoptosis, cellular polarization, protein fate and the unfolded protein response. It is possible that the decreased activity of various intracellular pathways explains the inability of cells to cope with the staurosporine insult and the consequent increased cell death.

$N$. crassa clearly translates changes in extracellular $\mathrm{Ca}^{2+}$ into a transcriptional response, since alterations in gene expression are caused alone by extracellular $\mathrm{Ca}^{2+}$ limitation or overload. This likely results from the homeostatic adaptation to the abnormal $\mathrm{Ca}^{2+}$ environment, i.e., the observed differences in gene expression might be triggered after the uptake or release of $\mathrm{Ca}^{2+}$ to balance the intracellular levels of the ion. Alternatively, these alterations may be secondary to the activity of a surface-localized $\mathrm{Ca}^{2+}$ sensor, although a sequence homologue of the extracellular $\mathrm{Ca}^{2+}$ sensing receptor of animals and plants $[46,47]$ has not been found so far in $N$. crassa. Given the predicted cell surface localization of the two putative novel $\mathrm{Ca}^{2+}$-binding proteins, NCU08524 and NCU06607, and the growth phenotype of the respective deletion strains under $\mathrm{Ca}^{2+}$ stress, it is tempting to speculate that they could play a role in $\mathrm{Ca}^{2+}$ sensing. The chemotropic interaction during conidial anastomosis tubes during cell fusion is $\mathrm{Ca}^{2+}$-dependent [43] and both NCU08524 and NCU06607 genes have been recently shown to be under the control of the PP-1 transcription factor, a regulator of cell fusion $[48,49]$.

In summary, we show that the effects of the antifungal [13-16, 50] and anticancer [51] agent staurosporine are robustly modulated by the accessibility to $\mathrm{Ca}^{2+}$ in the culture medium. The amount of extracellular $\mathrm{Ca}^{2+}$ affects staurosporine-triggered intracellular events like $\mathrm{Ca}^{2+}$ signaling, the production of ROS and cell death. Our results indicate that these differences are linked to the stimulation of unique transcriptional programs and further highlight the importance of $\mathrm{Ca}^{2+}$ during fungal cell death. In addition, our RNA-seq dataset will be a useful resource for investigations on the role of $\mathrm{Ca}^{2+}$ on different aspects of fungal biology.

\section{MATERIALS AND METHODS}

\section{Strains, culture media and chemicals}

Wild type 74-OR23-1VA strain and deletion mutants were obtained from the Fungal Genetics Stock Center [52] and handled with standard procedures [28]. Minimal medium refers to Vogel's medium containing $1.5 \%(\mathrm{w} / \mathrm{v})$ sucrose [27] plus $1.5 \%$ $(\mathrm{w} / \mathrm{v})$ agar to obtain solid medium. The concentration of $\mathrm{KH}_{2} \mathrm{PO}_{4}$ in the $50 x$ Vogel's stock solution was limited to $10 \mathrm{mM}$ to avoid precipitation with supplemental calcium [10]. The following chemicals were used: staurosporine (from LC Laboratories), dimethyl sulfoxide (DMSO), A23187, calcium chloride and sodium chloride (Sigma-Aldrich), phytosphingosine (Avanti Polar Lipids), 1,2-bis(ortho-aminophenoxy)ethane$\mathrm{N}, \mathrm{N}, \mathrm{N}^{\prime}, \mathrm{N}^{\prime}$-tetrasodium (BAPTA) (Merck Biochemicals).

\section{Growth assays}

Hyphal growth in solid medium at $26^{\circ} \mathrm{C}$ was obtained by measuring colony elongation after the inoculation of $20 \mu \mathrm{l}$ containing $5 \times 10^{4}$ conidia on the centre of large Petri dishes $(\varphi$ $14.2 \mathrm{~cm}$ ). Growth in liquid medium was examined by incubating $1 \times 10^{4}$ conidia $/ \mathrm{ml}$ at $26^{\circ} \mathrm{C}, 100 \mathrm{rpm}$, under constant light in 96-well plates $(200 \mu \mathrm{l} /$ well) and following absorbance at 450 nm [53] during 24 hours. The \% growth versus the respective control and the growth rate were calculated for each condition. For the spot assays, 3 -fold serial dilutions up to $1 \times 10^{4}$ cells $/ \mathrm{ml}$ were prepared for each strain. $5 \mu \mathrm{l}$ from each dilution were spotted on plates containing glucose-fructose-sorbose (GFS) [28] plus the relevant chemicals and incubated for 3 days at $26^{\circ} \mathrm{C}$.

\section{Flow cytometry measurements of cell death and reactive} oxygen species (ROS)

For each experiment and strain, a control without staining was prepared to define autofluorescence. Samples were read in a BD FACS Calibur and data analyzed with FlowJo (Tree Star). The levels of cell death were determined by staining cells with YOPRO-1 (Life Technologies) or propidium iodide (PI; SigmaAldrich). An inoculum of $10^{6}$ conidia/ml in the appropriate medium was incubated for 4 hours at $26^{\circ} \mathrm{C}$ (140 rpm, constant light). Staurosporine $(20 \mu \mathrm{M})$ was added and growth resumed for further 2 hours. The cells were harvested by centrifugation, washed twice with PBS and incubated either with $0.1 \mu \mathrm{M}$ YOPRO-1 (samples were kept $20 \mathrm{~min}$ on ice before reading) or $2 \mu \mathrm{g} / \mathrm{ml} \mathrm{PI}$ (samples were immediately ready for cytometry). The production of ROS was measured using the fluorescent probe dihydrorhodamine 123 (Sigma-Aldrich). After growing $10^{6}$ conidia/ml for 4 hours in the indicated medium at $26^{\circ} \mathrm{C}, 20$ $\mu \mathrm{g} / \mathrm{ml}$ dihydrorhodamine 123 and staurosporine were added for further 30 minutes. Samples were harvested by centrifugation and washed twice with PBS before being resuspended in $\mathrm{PBS}$ and read in the cytometer.

\section{Cytosolic $\mathrm{Ca}^{2+}$ measurements}

A bioluminescent method based on the reaction of cytosolic $\mathrm{Ca}^{2+}$ with the genetic probe aequorin in wild type cells was employed as previously described [12]. Briefly, $100 \mu$ lof conidia at a concentration of $2 \times 10^{6}$ cells $/ \mathrm{ml}, 5 \mu \mathrm{M}$ coelenterazine (Santa Cruz Biotechnology) and minimal medium were added to white opaque 96-well plates and incubated for 6 hours at $26^{\circ} \mathrm{C}$, in the dark, without agitation. Luminescence (in RLU, relative light units) was captured over time on a Bio-Tek Synergy HT microplate reader. Maximum levels of luminescence, determined in extra wells by measuring luminescence during 3 mins after the injection of $100 \mu \mathrm{l}$ of $3 \mathrm{M} \mathrm{CaCl}_{2}$ in $20 \%$ ethanol, were used to normalize each experiment (cytosolic $\mathrm{Ca}^{2+}$ levels (arbitrary units) $=$ experimental RLU values / total emitted luminescence). Quantification was performed by summing the normalized values and data are expressed as mean \pm SEM. The values from control DMSO-treated samples were subtracted from staurosporine-treated samples to obtain the "staurosporine-induced amplitude of response".

\section{Statistical and protein sequence analyses}

The non-parametric Mann-Whitney test was used for comparisons between two groups using SPSS 20 (SPSS Inc.) and pvalues $\leq 0.05$ were considered statistically significant. ClustalW2 [54] was used to align protein sequences and PSI-BLAST [55] was used for iterative searches. Secondary structure was predicted with MEMSAT3 [56], conserved domains with InterProScan [57], transmembrane domains with TMHMM 2.0 [58], subcellular localization with WoLF PSORT [59] and $\mathrm{Ca}^{2+}$ binding motifs with CaPS [20]. 


\section{High-throughput RNA sequencing (RNA-seq)}

Conidial suspensions of $1 \times 10^{6}$ cells $/ \mathrm{ml}$ were incubated in culture medium with the indicated concentration of $\mathrm{Ca}^{2+}$ for 6 hours $\left(26^{\circ} \mathrm{C}, 140 \mathrm{rpm}\right.$, constant light), staurosporine (or DMSO alone) was added and growth resumed for 1 more hour. Cells were harvested and immediately frozen in liquid nitrogen. RNA isolation, mRNA purification and fragmentation and CDNA synthesis was performed as previously described [15]. The cDNA libraries were generated using an Illumina TruSeq kit and sequenced in an Illumina HiSeq2000 (single reads of $50 \mathrm{bp}$ were obtained). Sequencing data was handled with Tophat, Cufflinks and Cuffdiff and expression levels are presented as Fragments Per Kilobase of transcript per Million mapped reads (FPKM). Functional enrichment of sets of genes was assessed with FunCat [60]. The resulting dataset is available at the NCBI GEO database (http://www.ncbi.nlm.nih.gov/geo/; series record: GSE53013).

\section{ACKNOWLEDGMENTS}

We would like to thank Dr. Nick D Read (Manchester Fungal Infection Group, Institute of Inflammation and Repair, University of Manchester, UK) for providing the aequorin-containing plasmid. A.P.G. was recipient of a fellowship from Fundação Calouste Gulbenkian (104210) and a short-term fellowship from EMBO (329-2012). J.M.C. was hired under the scope of FCT Portugal CIÊNCIA 2008 Programme (FSE-POPH-QREN). This work was supported by FCT Portugal (PEstC/SAU/LA0002/2013 and FCOMP-01-0124-FEDER-037277 to A.V. and PEst-OE/SAU/UI0215/2014 to P.C.S.), the European

\section{REFERENCES}

1. Shaw BD, Hoch HC (2001). Biology of the fungal cell. In: Howard RJ, Gow NAR, editors. The Mycota VIII. Springer-Verlag KG, Berlin; pp 7389.

2. Zhivotovsky B, Orrenius S (2011). Calcium and cell death mechanisms: a perspective from the cell death community. Cell Calcium 50(3): 211-221.

3. Pozniakovsky AI, Knorre DA, Markova OV, Hyman AA, Skulachev VP, Severin FF (2005). Role of mitochondria in the pheromone- and amiodarone-induced programmed death of yeast. J Cell Biol 168(2): 257-269.

4. Rao A, Zhang Y, Muend S, Rao R (2010). Mechanism of antifungal activity of terpenoid phenols resembles calcium stress and inhibition of the TOR pathway. Antimicrob Agents Chemother 54(12): 50625069.

5. Roberts SK, McAinsh M, Widdicks L (2012). Cch1p mediates Ca ${ }^{2+}$ influx to protect Saccharomyces cerevisiae against eugenol toxicity. PLoS One 7(9): e43989.

6. Gupta SS, Ton VK, Beaudry V, Rulli S, Cunningham K, Rao R (2003). Antifungal activity of amiodarone is mediated by disruption of calcium homeostasis. J Biol Chem 278(31): 28831-28839.

7. Bonilla M, Nastase KK, Cunningham KW (2002). Essential role of calcineurin in response to endoplasmic reticulum stress. EMBO J 21(10): 2343-2353.

8. Martin DC, Kim H, Mackin NA, Maldonado-Baez L, Evangelista CC, Jr., Beaudry VG, Dudgeon DD, Naiman DQ, Erdman SE, Cunningham KW (2011). New regulators of a high affinity $\mathrm{Ca}^{2+}$ influx system revealed through a genome-wide screen in yeast. J Biol Chem 286(12): 1074410754.
$\mathrm{POCl}$ program of QCAll co-participated by FEDER (NORTE-070124-FEDER-000003), a grant from the University of Porto (PP_IJUP2011-20 to A.V.) and a grant from the National Institutes of Health (NIH R24 GM081597 to N.L.G. with Drs. JW Taylor and RB Brem).

\section{SUPPLEMENTAL MATERIAL}

All supplemental data for this article are available online at www.microbialcell.com.

\section{CONFLICT OF INTEREST}

The authors declare no conflict of interest.

\section{COPYRIGHT}

(C) 2014 Gonçalves et al. This is an open-access article released under the terms of the Creative Commons Attribution (CC BY) license, which allows the unrestricted use, distribution, and reproduction in any medium, provided the original author and source are acknowledged.

Please cite this article as: A. Pedro Gonçalves, João Monteiro, Chiara Lucchi, David J. Kowbel, J. Miguel Cordeiro, Paulo Correiade-Sá, Daniel J. Rigden, N. Louise Glass, Arnaldo Videira (2014). Extracellular calcium triggers unique transcriptional programs and modulates staurosporine-induced cell death in Neurospora crassa. Microbial Cell 1(9): 289-302. doi: 10.15698/mic2014.09.165

9. Palma-Guerrero J, Huang IC, Jansson HB, Salinas J, Lopez-Llorca LV Read ND (2009). Chitosan permeabilizes the plasma membrane and kills cells of Neurospora crassa in an energy dependent manner. Fungal Genet Biol 46(8): 585-594

10. Binder U, Chu M, Read ND, Marx F (2010). The antifungal activity of the Penicillium chrysogenum protein PAF disrupts calcium homeostasis in Neurospora crassa. Eukaryot Cell 9(9): 1374-1382.

11. Munoz A, Marcos JF, Read ND (2012). Concentration-dependent mechanisms of cell penetration and killing by the de novo designed antifungal hexapeptide PAF26. Mol Microbiol 85(1): 89-106.

12. Gonçalves AP, Cordeiro JM, Monteiro J, Muñoz A, Correia-de-Sá P, Read ND, Videira A (2014). Activation of a TRP-like channel and intracellular calcium dynamics during phospholipase C-mediated cell death. J Cell Sci. (In press)

13. Castro A, Lemos C, Falcao A, Fernandes AS, Glass NL, Videira A (2010). Rotenone enhances the antifungal properties of staurosporine. Eukaryot Cell 9(6): 906-914.

14. Fernandes AS, Castro A, Videira A (2013). Reduced glutathione export during programmed cell death of Neurospora crassa. Apoptosis 18(8): 940-948.

15. Goncalves AP, Hall C, Kowbel DJ, Glass NL, Videira A (2014). CZT-1 Is a Novel Transcription Factor Controlling Cell Death and Natural Drug Resistance in Neurospora crassa. G3 (Bethesda) 4(6): 1091-1102.

16. Fernandes AS, Goncalves AP, Castro A, Lopes TA, Gardner R, Glass NL, Videira $A$ (2011). Modulation of fungal sensitivity to staurosporine by targeting proteins identified by transcriptional profiling. Fungal Genet Biol 48(12): 1130-1138. 
17. Galagan JE, Calvo SE, Borkovich KA, Selker EU, Read ND, Jaffe $D$, FitzHugh W, Ma $\amalg$, Smirnov S, Purcell S, Rehman B, Elkins T, Engels R, Wang $S$, Nielsen CB, Butler J, Endrizzi $M$, Qui D, lanakiev $P$, BellPedersen $D$, Nelson MA, Werner-Washburne $M$, Selitrennikoff $C P$, Kinsey JA, Braun EL, Zelter A, Schulte U, Kothe GO, Jedd G, Mewes W, et al. (2003). The genome sequence of the filamentous fungus Neurospora crassa. Nature 422(6934): 859-868.

18. Borkovich KA, Alex LA, Yarden O, Freitag M, Turner GE, Read ND, Seiler S, Bell-Pedersen D, Paietta J, Plesofsky N, Plamann M, GoodrichTanrikulu M, Schulte U, Mannhaupt G, Nargang FE, Radford A, Selitrennikoff C, Galagan JE, Dunlap JC, Loros JJ, Catcheside D, Inoue H, Aramayo R, Polymenis M, Selker EU, Sachs MS, Marzluf GA, Paulsen I, Davis R, Ebbole DJ, et al. (2004). Lessons from the genome sequence of Neurospora crassa: tracing the path from genomic blueprint to multicellular organism. Microbiol Mol Biol Rev 68(1): 1-108.

19. Zelter A, Bencina M, Bowman BJ, Yarden O, Read ND (2004). A comparative genomic analysis of the calcium signaling machinery in Neurospora crassa, Magnaporthe grisea, and Saccharomyces cerevisiae. Fungal Genet Biol 41(9): 827-841.

20. Zhou Y, Yang W, Kirberger M, Lee HW, Ayalasomayajula G, Yang JJ (2006). Prediction of EF-hand calcium-binding proteins and analysis of bacterial EF-hand proteins. Proteins 65(3): 643-655.

21. Santamaria-Hernando S, Krell T, Ramos-Gonzalez MI (2012). Identification of a novel calcium binding motif based on the detection of sequence insertions in the animal peroxidase domain of bacterial proteins. PLoS One 7(7): e40698.

22. Rigden DJ, Woodhead DD, Wong PW, Galperin MY (2011). New structural and functional contexts of the Dx[DN]xDG linear motif: insights into evolution of calcium-binding proteins. PLoS One 6(6): e21507.

23. Rigden DJ, Galperin MY (2004). The DxDxDG motif for calcium binding: multiple structural contexts and implications for evolution. Mol Biol 343(4): 971-984.

24. Rigden DJ, Jedrzejas MJ, Moroz OV, Galperin MY (2003). Structural diversity of calcium-binding proteins in bacteria: single-handed EFhands? Trends Microbiol 11(7): 295-297.

25. Naested H, Frandsen GI, Jauh GY, Hernandez-Pinzon I, Nielsen HB, Murphy DJ, Rogers JC, Mundy J (2000). Caleosins: Ca ${ }^{2+}$-binding proteins associated with lipid bodies. Plant Mol Biol 44(4): 463-476.

26. Cioci G, Mitchell EP, Chazalet V, Debray H, Oscarson S, Lahmann M Gautier C, Breton C, Perez S, Imberty A (2006). Beta-propeller crystal structure of Psathyrella velutina lectin: an integrin-like fungal protein interacting with monosaccharides and calcium. J Mol Biol 357(5): 1575-1591.

27. Vogel HJ (1956). A convenient growth medium for Neurospora (Medium N). Microbial Genet Bull 13: 42-43.

28. Davis RH, de Serres FJ (1970). Genetic and microbiological research techniques for Neurospora crassa. Meth Enzymol 17:79-143.

29. Castro A, Lemos C, Falcao A, Glass NL, Videira A (2008). Increased resistance of complex I mutants to phytosphingosine-induced programmed cell death. J Biol Chem 283(28): 19314-19321.

30. Videira A, Kasuga T, Tian C, Lemos C, Castro A, Glass NL (2009). Transcriptional analysis of the response of Neurospora crassa to phytosphingosine reveals links to mitochondrial function. Microbiology 155(Pt 9): 3134-3141.

31. Bick AG, Calvo SE, Mootha VK (2012). Evolutionary diversity of the mitochondrial calcium uniporter. Science 336(6083): 886.

32. Cavinder B, Trail F (2012). Role of Fig1, a component of the lowaffinity calcium uptake system, in growth and sexual development of filamentous fungi. Eukaryot Cell 11(8): 978-988.
33. Herwig C, Doerries C, Marison I, von Stockar U (2001). Quantitative analysis of the regulation scheme of invertase expression in Saccharomyces cerevisiae. Biotechnol Bioeng 76(3): 247-258.

34. Ziv C, Gorovits R, Yarden O (2008). Carbon source affects PKAdependent polarity of Neurospora crassa in a CRE-1-dependent and independent manner. Fungal Genet Biol 45(2): 103-116

35. Benito B, Garciadeblas B, Rodriguez-Navarro A (2000). Molecular cloning of the calcium and sodium ATPases in Neurospora crassa. Mol Microbiol 35(5): 1079-1088.

36. Rodrigues JJ, Ferreira HB, Farias SE, Zaha A (1997). A protein with a novel calcium-binding domain associated with calcareous corpuscles in Echinococcus granulosus. Biochem Biophys Res Commun 237(2): 451-456.

37. Edlind T, Smith L, Henry K, Katiyar S, Nickels J (2002). Antifungal activity in Saccharomyces cerevisiae is modulated by calcium signalling. Mol Microbiol 46(1): 257-268.

38. Bowman BJ, Abreu S, Margolles-Clark E, Draskovic M, Bowman EJ (2011). Role of four calcium transport proteins, encoded by nca-1, nca-2, nca-3, and cax, in maintaining intracellular calcium levels in Neurospora crassa. Eukaryot Cell 10(5): 654-661.

39. Bowman BJ, Draskovic M, Freitag M, Bowman EJ (2009). Structure and distribution of organelles and cellular location of calcium transporters in Neurospora crassa. Eukaryot Cell 8(12): 1845-1855.

40. Bowman BJ, Abreu S, Johl JK, Bowman EJ (2012). The pmr gene, encoding a $\mathrm{Ca}^{2+}$-ATPase, is required for calcium and manganese homeostasis and normal development of hyphae and conidia in Neurospora crassa. Eukaryot Cell 11(11): 1362-1370.

41. Strayle J, Pozzan T, Rudolph HK (1999). Steady-state free $\mathrm{Ca}^{2+}$ in the yeast endoplasmic reticulum reaches only 10 microM and is mainly controlled by the secretory pathway pump pmr1. EMBO J 18(17): 4733-4743.

42. Deka R, Tamuli R (2013). Neurospora crassa ncs-1, mid-1 and nca-2 double-mutant phenotypes suggest diverse interaction among three $\mathrm{Ca}^{2+}$-regulating gene products. J Genet 92(3): 559-563.

43. Palma-Guerrero J, Hall CR, Kowbel D, Welch J, Taylor JW, Brem RB, Glass NL (2013). Genome wide association identifies novel loci involved in fungal communication. PLoS Genet 9(8): e1003669.

44. Deka R, Kumar R, Tamuli R (2011). Neurospora crassa homologue of Neuronal Calcium Sensor-1 has a role in growth, calcium stress tolerance, and ultraviolet survival. Genetica 139(7): 885-894.

45. Park G, Servin JA, Turner GE, Altamirano L, Colot HV, Collopy $P$, Litvinkova L, Li L, Jones CA, Diala FG, Dunlap JC, Borkovich KA (2011). Global analysis of serine-threonine protein kinase genes in Neurospora crassa. Eukaryot Cell 10(11): 1553-1564.

46. Brown EM, Gamba G, Riccardi D, Lombardi M, Butters R, Kifor O, Sun A, Hediger MA, Lytton J, Hebert SC (1993). Cloning and characterization of an extracellular $\mathrm{Ca}^{2+}$-sensing receptor from bovine parathyroid. Nature 366(6455): 575-580.

47. Han S, Tang R, Anderson LK, Woerner TE, Pei ZM (2003). A cell surface receptor mediates extracellular $\mathrm{Ca}^{2+}$ sensing in guard cells. Nature 425(6954): 196-200.

48. Leeder AC, Jonkers W, Li J, Glass NL (2013). Early colony establishment in Neurospora crassa requires a MAP kinase regulatory network. Genetics 195(3): 883-898

49. Palma-Guerrero J, Leeder AC, Welch J, Glass NL (2014). Identification and characterization of LFD1, a novel protein involved in membrane merger during cell fusion in Neurospora crassa. Mol Microbiol 92(1): 164-182. 
50. Gonçalves AP, Videira A (2014). Programmed cell death in Neurospora crassa. New J Sci 2014. Article ID 479015.

51. Gescher A (2000). Staurosporine analogues - pharmacological toys or useful antitumour agents? Crit Rev Oncol Hematol 34(2): 127-135.

52. McCluskey K, Wiest A, Plamann M (2010). The Fungal Genetics Stock Center: a repository for 50 years of fungal genetics research. J Biosci 35(1): 119-126.

53. Alberghina FA (1973). Growth regulation in Neurospora crassa. Effects of nutrients and of temperature. Arch Mikrobiol 89(2): 83-94.

54. Larkin MA, Blackshields G, Brown NP, Chenna R, McGettigan PA, McWilliam H, Valentin F, Wallace IM, Wilm A, Lopez R, Thompson JD, Gibson TJ, Higgins DG (2007). Clustal W and Clustal X version 2.0. Bioinformatics 23(21): 2947-2948.

55. Altschul SF, Madden TL, Schaffer AA, Zhang J, Zhang Z, Miller W, Lipman DJ (1997). Gapped BLAST and PSI-BLAST: a new generation of protein database search programs. Nucleic Acids Res 25(17): 33893402.

56. Jones DT (2007). Improving the accuracy of transmembrane protein topology prediction using evolutionary information. Bioinformatics 23(5): 538-544.
57. Quevillon E, Silventoinen V, Pillai S, Harte N, Mulder N, Apweiler R, Lopez R (2005). InterProScan: protein domains identifier. Nucleic Acids Res 33(Web Server issue): W116-120.

58. Krogh A, Larsson B, von Heijne G, Sonnhammer EL (2001). Predicting transmembrane protein topology with a hidden Markov model: application to complete genomes. J Mol Biol 305(3): 567-580.

59. Horton P, Park KJ, Obayashi T, Fujita N, Harada H, Adams-Collier CJ, Nakai K (2007). WoLF PSORT: protein localization predictor. Nucleic Acids Res 35(Web Server issue): W585-587.

60. Ruepp A, Zollner A, Maier D, Albermann K, Hani J, Mokrejs M, Tetko I, Guldener U, Mannhaupt G, Munsterkotter M, Mewes HW (2004). The FunCat, a functional annotation scheme for systematic classification of proteins from whole genomes. Nucleic Acids Res 32(18): 5539-5545.

61. Ochiai A, Itoh T, Maruyama Y, Kawamata A, Mikami B, Hashimoto $W$, Murata $K$ (2007). A novel structural fold in polysaccharide lyases: Bacillus subtilis family 11 rhamnogalacturonan lyase YesW with an eight-bladed beta-propeller. J Biol Chem 282(51): 37134-37145.

62. Wilson MA, Brunger AT (2000). The $1.0 \mathrm{~A}$ crystal structure of $\mathrm{Ca}^{2+}$ bound calmodulin: an analysis of disorder and implications for functionally relevant plasticity. J Mol Biol 301(5): 1237-1256. 